\title{
Analysis of natural formaldehyde formation on several types of marine fish circulating in Jakarta
}

\author{
Meida $^{1 *}$, Suyud Warno Utomo ${ }^{1,2}$, and Mufti Petala Patria ${ }^{1,3}$ \\ ${ }^{1}$ School of Environmental Science, Universitas Indonesia, Central Jakarta 10430, Indonesia \\ ${ }^{2}$ Department of Environmental Health, Faculty of Public Health, Universitas Indonesia, \\ Depok, 16424 Indonesia \\ ${ }^{3}$ Department of Biology, Faculty of Math and Science, Universitas Indonesia, Depok, 16424 \\ Indonesia
}

\begin{abstract}
Formaldehyde is dangerous to health because it is a carcinogen that can cause cancer. Jakarta Province has an integrated food control program, namely fish supervision, free from formaldehyde. The test results during the management there were several fish containing formaldehyde, namely moonfish (Lampris guttatus), hardtail scad (Megalaspis cordyla), rank goby (Saurida tumbill), and mackerel scad (Decapterus spp). There is no information regarding the detected formaldehyde in these fish, so this study aims to analyze the natural formaldehyde formation process of the four types of marine fish to ensure that the detected formaldehyde results from addition or naturally occurring. This study also describes how fishers in Jakarta consider environmental factors in the fish handling process. This study used a completely randomized design and ANOVA in determining levels of formaldehyde. The qualitative approach carried out using interviews and observations. The parameters studied were formaldehyde levels, Total Volatile Base (TVB), and Trimethyl Amin (TMA). The results showed that moonfish, hardtail scad, rank goby, and mackerel scad increased natural formaldehyde content during storage, namely $0 \mathrm{mg} / \mathrm{kg}$ on day 0 to $6.51 \mathrm{mg} / \mathrm{kg}$ on day 18 . The formation of natural formaldehyde in the four types of samples during storage in freezing temperature correlates with the degradation process based on the TVB and TMA parameters. Although the fishermen understand that environmental factors determine natural formaldehyde formation in fish, they are not worried because it does not directly impact consumers' health. Therefore, it is necessary to increase
\end{abstract}

\footnotetext{
* Corresponding author : meida@ui.ac.id
} 
environmental awareness for anglers to maintain consumer health.

\section{Introduction}

To achieve improvements in the Sustainable Development Goals (SDGs), the existence of a healthy national food control system plays an essential role in protecting consumer health, ensuring food security, and facilitating fair trade [1]. At present, there are many reports about the formaldehyde content in fresh fish [2], which is one of the social problems related to food safety in developing countries such as Malaysia, Indonesia, Thailand, and Bangladesh [3]. In 2002, WHO reported that high formaldehyde concentrations were found in marine fish when exposed to the environment longer without proper preservation [4]. Although a ban on formaldehyde has been enforced, there are still reports of illegal addition of this compound by fish sellers without regard for consumer safety [5].

Seafood is an essential part of a healthy diet, but seafood contamination can make it a source of foodborne diseases [6]. To ensure safe food for humans, a significant problem commonly faced in developed countries is quality compared to product prices [7]. Recent trends in food chain production, processing, distribution, and preparation enhance research to ensure global food supplies' security as consumers worldwide recognize the importance of health, balanced nutrition, and safe consumption [8,9]. Among the many contaminants, attention has been paid to toxic volatile aldehydes such as formaldehyde, which is classified by the International Agency for Research on Cancer, in Group 1 as a human carcinogen that can cause cancer, asthma, lung damage, and leukemia in humans [10]-[12]. Besides, the consumption of foods containing formaldehyde can damage the nervous system, kidneys, liver [13]-[15]. Therefore, it is crucial to investigate the formaldehyde content in fish, which is claimed to be the primary contaminant of seafood, to understand the risks of consumption and provide food safety information [5].

The World Health Organization (WHO) estimates that formaldehyde levels are in the range of 1.5-14 mg/day (average $7.75 \mathrm{mg}$ /day) for the average adult [4]. Meanwhile, according to the European Food Safety Agency (EFSA), daily formaldehyde exposure from the total diet should not exceed $100 \mathrm{mg}$ formaldehyde per day [11], [16]. In Indonesia, the threshold value for formalin in the air, according to the National Standardization Agency for Indonesia [17], is $0.37 \mathrm{mg} / \mathrm{m}^{3}$ for the highest permissible level.

Fish can produce formaldehyde from their bodies that naturally occur during the decomposition process; in dead fish, quality changes arise due to enzyme, biochemical, microbiological, and physical activity [18]. Formaldehyde is an enzymatic decomposition product of Trimethylamine oxide (TMAO) in fish during post-mortem storage and, as a byproduct, is Dimethylamine (DMA) [19]. Trimethylamine oxide demethylase (TMAOase) is an endogenous enzyme that plays a role in the breakdown of TMAO into formaldehyde and DMA [20]. The TMAOase enzyme has been detected in many Gadoid fish species and plays an essential role during frozen fish's deterioration process [21]. Fish must remain fresh until it reaches the final consumer, and this can only do by keeping it in freezing temperatures [22]. In practice, fish can go through many stages before entering the processing plant, thus increasing the handling time, which leads to decreased quality [23]. The decline in fish 
quality can be caused by two factors, namely internal factors such as types of species and characteristics of fish meat, and external factors such as environment, cleanliness, storage temperature, handling, and transportation methods [19, 24, 25].

Jakarta Province has an integrated food control program to supervise fish in 125 markets in Jakarta free from dangerous substances such as formalin. This integrated food control program is carried out by taking fresh fish samples from markets and fisheries centers in Jakarta and then conducting on the spot formaldehyde testing by the Fisheries Product Inspection and Certification Production Center laboratory using a mobile laboratory car. According to the test results, there were several fish that contained formaldehyde, including moonfish (Lampris guttatus), hardtail scad (Megalaspis cordyla), rank goby (Saurida tumbill), and mackerel scad (Decapterus spp). Therefore, it is essential to investigate these fish's formaldehyde content to understand the risk of consumption and provide food safety information.

There is no clear information regarding the formaldehyde detected in moonfish (Lampris guttatus), hardtail scad (Megalaspis cordyla), rank goby (Saurida tumbill), and mackerel scad (Decapterus spp), so research to analyze the possibility of formaldehyde formation. This research was conducted to ascertain the origin of the formaldehyde detected in these fish is the result of addition or naturally formed. Besides, it is also necessary to explain how the Jakarta fishing community considers environmental factors in the fish handling process. Therefore, this study aims to analyze the formaldehyde from these fish and the ecological factors in fish handling to ensure food safety for fishery products circulating in Jakarta.

\section{Method}

The research materials used were four types of fresh fish, namely moonfish (Lampris guttatus), hardtail scad (Megalaspis cordyla), rank goby (Saurida tumbill), and mackerel scad (Decapterus spp). These four commercial fish types are selected as target samples based on integrated food safety monitoring in Jakarta Province, where four types of fish are indicated to contain formaldehyde. The weight of the fish used for moonfish is $15700 \pm 2500$ $\mathrm{g}$, hardtail scad $350 \pm 15 \mathrm{~g}$, rank goby $250 \pm 25 \mathrm{~g}$, and mackerel scad $250 \pm 20 \mathrm{~g}$. Samples of hardtail scad, rank goby, and mackerel scad in the form of whole fish obtained from fishing boats landed by the Muara Angke fish landing center, while moonfish fish purchased at the Muara Baru modern fish market in the form of fillet fish. Fish samples brought to the laboratory in Jakarta packed in insulated crates containing crushed ice in layers with a 1:3 between fish and ice. Furthermore, each fish's meat divides into seven groups, stored at freezing temperature, and observed every three days for 18 days to see the amount of formaldehyde content formed.

According to the National Standardization Agency, the determination of formaldehyde formation in the four types of fish first analyzed the proximate composition on the first day, namely moisture content, ash content, protein content, and fat content. Furthermore, analysis of Total Volatile Base (TVB) and Trimetil Amin (TMA) levels carried out using the Conway method. The concentration of formaldehyde is determined in two stages. The first stage is 
the extraction of fish samples using Nash's extraction method (1953). The next step is to measure formaldehyde concentration in the appropriate sample using the Perkin Elmer Lambda 25 UV/VIS Spectrophotometer $[19,26]$. This study used a completely randomized design (CRD), and the data were analyzed statistically by analysis of variance (ANOVA).

This study also describes how the Jakarta fishing community considers environmental factors in the fish handling process using a qualitative approach through interviews. The qualitative approach in this study refers to previous research, where the researcher is a critical instrument that collects data through documentation, observes the behavior of respondents or participants, and interviews [27]. Using accidental snowball techniques, nine respondents selected for the interview; three respondents are fishermen, three workers on fishing boats, and three moonfish sellers in Muara Baru. The selected fishermen and boat workers come from fishing boats that catch hardtail scad, rank goby, and mackerel scad. All data in the form of interview transcripts were analyzed using qualitative descriptive methods and presented in narrative form.

\section{Results and discussion}

\subsection{Proximate composition analysis}

The chemical composition of fish meat plays a role in making formaldehyde in a fish's body after death [28]. Proximate analysis is needed to see the rate of spoilage in fish; chemical damage can be caused by protein denaturation and fat oxidation [18]. The higher the protein and fat content in fish, the faster it causes changes in fish. The proximate analysis of the four types of fish in this study is present in Table 1.

Tabel 1. Proximate composition of moonfish, hardtail scad, rank goby, and mackerel scad

\begin{tabular}{|l|c|c|c|c|}
\hline \multicolumn{1}{|c|}{ Kind of Fish } & $\begin{array}{c}\text { Moisture } \\
\text { Content } \\
(\%)\end{array}$ & $\begin{array}{c}\text { Ash Content } \\
(\%)\end{array}$ & $\begin{array}{c}\text { Protein } \\
\text { Levels (\%) }\end{array}$ & $\begin{array}{c}\text { Fat Levels } \\
(\%)\end{array}$ \\
\hline Moonfish (Lampris guttatus) & 70,98 & 2,05 & 34,14 & 12,63 \\
\hline $\begin{array}{l}\text { Hardtail scad (Megalaspis } \\
\text { cordyla) }\end{array}$ & 74,3 & 2,51 & 30,32 & 6,11 \\
\hline Rank goby (Saurida tumbill) & 74,95 & 2,19 & 29,06 & 3,74 \\
\hline Mackerel scad (Decapterus spp) & 73,54 & 3,62 & 31,47 & 1,9 \\
\hline
\end{tabular}

In Table 1, it can see that the fish meat with the lowest water content parameter $(70.98 \%)$ was moonfish, while the highest $(74.95 \%)$ was ranked goby. In the ash content parameter, fish with the lowest range $(2.05 \%)$ was moonfish, and mackerel scad had the highest ash content $(3.62 \%)$. The fish with the highest protein content $(34.14 \%)$ was moonfish, while the lowest $(29.06 \%)$ was owned by rank. Moonfish fat content $(12.63 \%)$ is the highest among the four types of fish, saying that moonfish is a high-fat fish. The chemical composition of fish depends on species, age, sex, fishing season, habitat, and environmental conditions. The 
protein and mineral content of fish meat is relatively constant, but water content and fat content fluctuate widely. If the fat content in beef is bigger, the water content will be smaller and vice versa [29]. The fat content of meat directly correlates with the total microbial growth in fish meat [18]. Probably a pathway for formaldehyde formation, which is why the natural formaldehyde content in fish with high-fat content tends to be higher than fish with low-fat content [30].

\subsection{TVB, TMA, and Formaldehyde content}

In fish after death, there is a change in quality, which leads to spoilage caused by enzyme, biochemical, physical, and microbiological activity [18]. Natural formaldehyde formation can occur during the decomposition process; the more rotten the fish, the higher the natural formaldehyde [24]. During both cold and frozen storage, the decomposition of TMAO in fish and other marine products will produce TMA, TVB, and formaldehyde [30]. TVB, TMA, and formaldehyde analysis results for four types of fish study are present in Figures 1, 2, and 3.

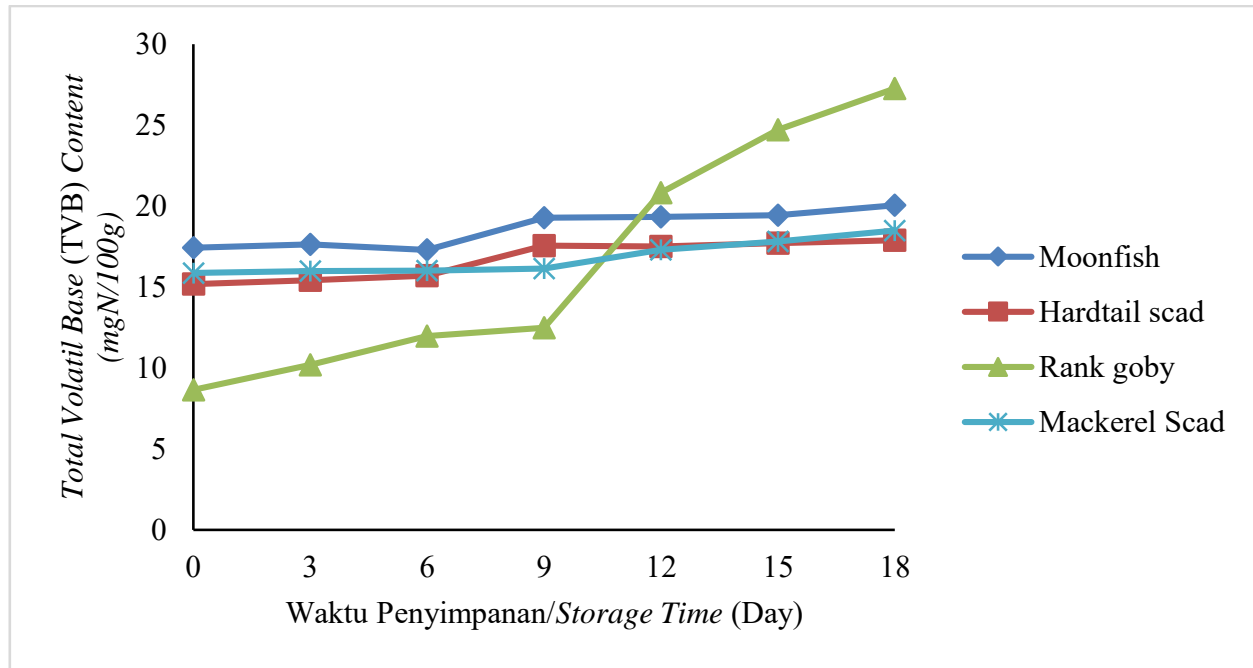

Fig. 1. TVB Content (mgN/100g) of Fish During Frozen Storage

Figure 1 shows the results of TVB testing on four types of fish during freezing temperature storage. The TVB content of four types of fish increased during freezing temperatures, especially in rank goby fish after nine days of storage increased sharply on the 12th day with TVB content already above $20 \mathrm{mgN} / 100 \mathrm{~g}$, which was low quality. The content of TVB is an indicator of fish spoilage, the limit for fish to be declared rotten, according to SNI 2354.8:2009, is the level of TVB $20 \mathrm{mgN} / 100 \mathrm{~g}$ [31]. Meanwhile, moonfish fish showed rot on the 18th day of storage with a TVB content of $20.05 \mathrm{mgN} / 100 \mathrm{~g}$, and an increase of $3.37 \mathrm{mgN} / 100 \mathrm{~g}$ from day 0.TVB content continued to increase during storage. Due to the 
occurrence of deterioration of quality or spoilage of fish meat. On the 18th day, the TVB content for moonfish, hardtail scad, rank goby, and mackerel scad were $20.05 ; 17.89 ; 27.26$, and $18.49 \mathrm{mgN} / 100 \mathrm{~g}$. It means that each type of fish's durability or durability varies based on the formed TVB content.

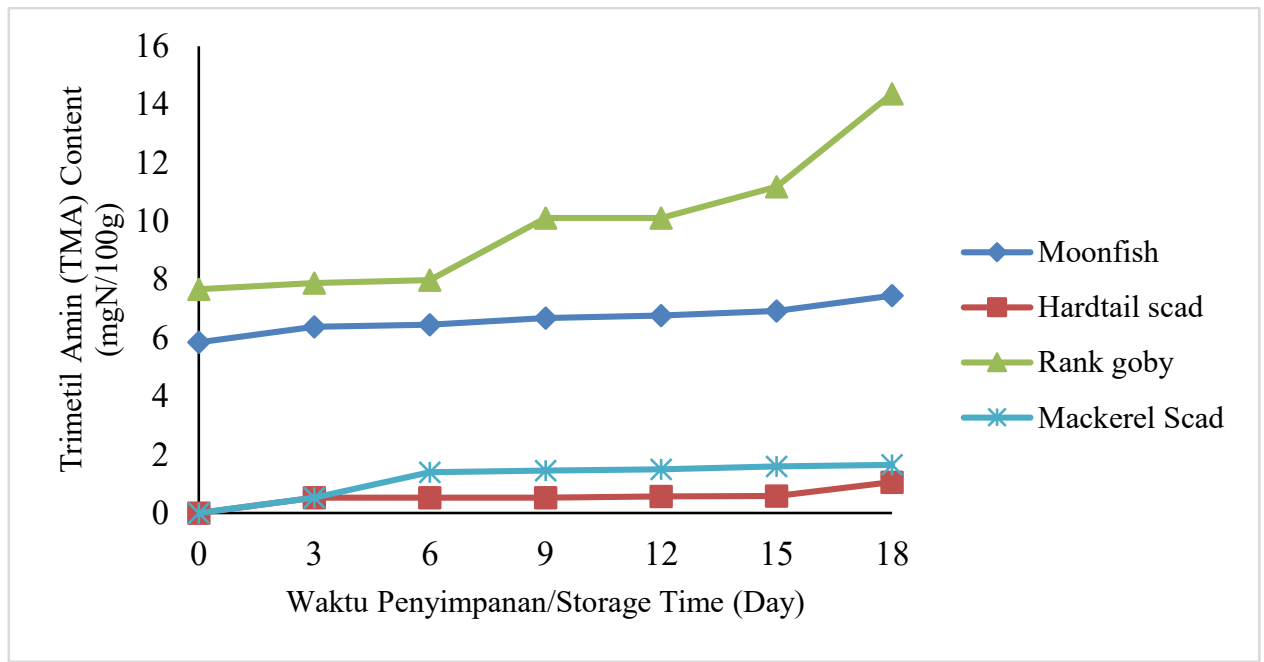

Fig. 2. TMA Content (mgN/100g) of Fish During Frozen Storage

TMA measurement data for four types of fish during storage at freezing temperature is present in Figure 2 that shows that the TMA content of fish stored at freezing on day 18 for moonfish, hardtail scad, rank goby, and mackerel scads is $7.45 ; 1.06 ; 14.37$; and 1.65 $\mathrm{mgN} / 100 \mathrm{~g}$. From the test results, it can see that the TMA content increases during cold storage; this is in line with the increase in TVB content because TMA is part of TVB so that its value is always lower than TVB [18]. TMA is a compound that provides a characteristic fishy odor from fish $[32,33]$. TMA formation occurs in several stages, namely the first occurrence of choline oxidation by bacteria, which cuts the trimethylammonium group from choline to form trimethylamine-oxide (TMAO), then TMAO undergoes a reduction reaction to form TMA by enzymes [34]. The time and temperature of fish storage play an essential role in various formaldehyde content levels in fish species [35]. TMAO is more available in marine fish than in freshwater fish because of its function in the osmoregulation system. The formaldehyde produced naturally in marine fish muscles by bacteria or enzyme reactions becomes covalently bound in cross-links between peptide chains [10]. 


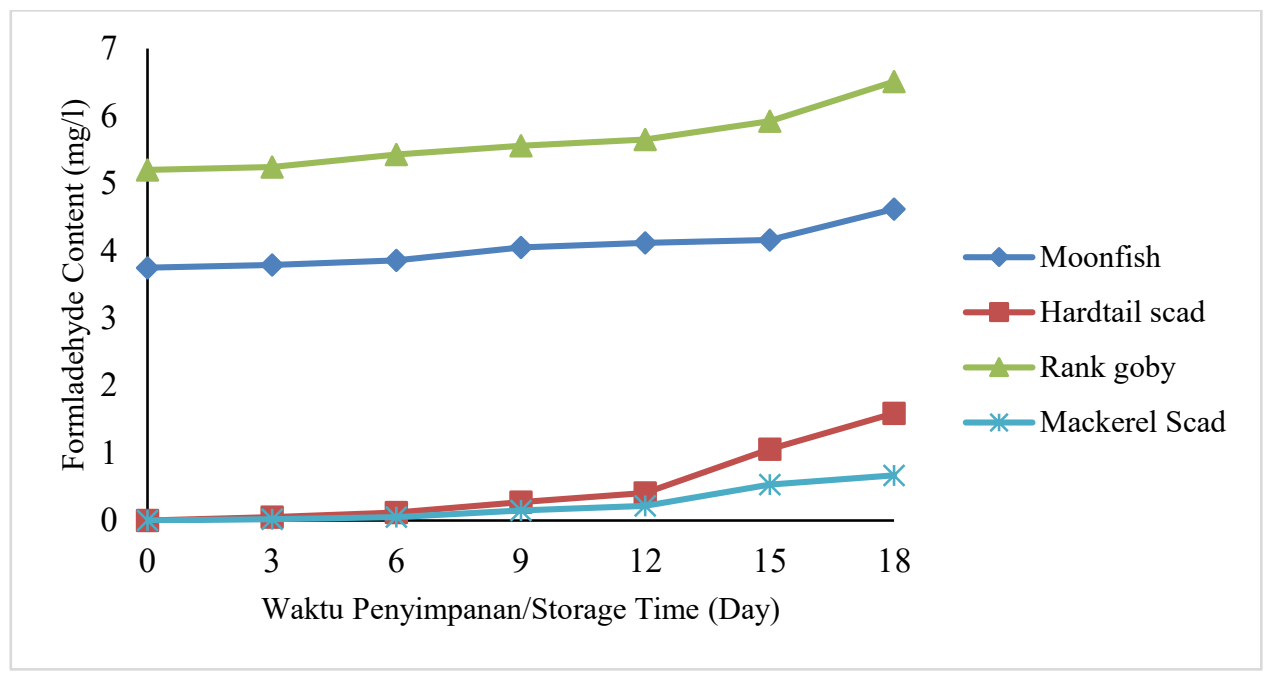

Fig. 3. Formaldehyde Content (mgN/100g) of Fish During Frozen Storage

The formaldehyde test results in Figure 3 were carried out based on SNI 2354-18: 2018 using the spectrophotometric [36]. Figure 3 shows that fish's formaldehyde content stored at a cold temperature on day 18 for hardtail scad and mackerel scad was 1.59 and $0.67 \mathrm{mg} / \mathrm{kg}$. The condition of the fish was still relatively fresh at that time, seen from the TVB value of fish meat, which was still below $20 \mathrm{mgN} / 100 \mathrm{~g}$ except for moonfish and rank goby whose TVB values exceeded the standard of fresh fish and contained formaldehyde of 4.62 and 6.51 $\mathrm{mg} / \mathrm{kg}$. The effectiveness of using freezing temperatures in inhibiting fish quality degradation can see from the low level of formaldehyde content until the 18th day of storage. The enzyme activity that breaks down TMAO is inhibited due to the use of freezing temperatures.

This finding is in line with a research, which stated that the concentration of natural formaldehyde in fresh Opah fish ranged from $4.62 \pm 0.00 \mathrm{mg} / \mathrm{kg}$ to $58.10 \pm 0.46 \mathrm{mg} / \mathrm{kg}$ [28]. It is also in line with the natural formaldehyde research of beloso fish stated that the results on the observation day 0 were $0.22 \mathrm{mg} / \mathrm{kg}$ and continued to increase up to $7.45 \mathrm{mg} / \mathrm{kg}$ on the 16th day of observation [2]. Natural formaldehyde for hardtail scad fish and mackerel scad was also presented in the study in previous study, which stated that the concentration of formaldehyde hardtail scad was 1.37 and $0.87 \mathrm{mg} / \mathrm{kg}$ [30].

The World Health Organization (WHO) informs that in fishery products, natural formaldehyde content can be detected from a concentration of $1-98 \mathrm{mg} / \mathrm{kg}$. This formaldehyde content varies depending on the type of food product [4]. Based on the test data for the four types of fish, it can conclude that the formaldehyde content formed during 18 days of storage at freezing temperature does not exceed the threshold set by WHO 1.5-14 $\mathrm{mg} /$ day and EFSA $100 \mathrm{mg}$ per day. Although formaldehyde in fish occurs naturally, the dangerous risks of formaldehyde for health are the same as formaldehyde added illegally to food [28]. 


\subsection{Formaldehyde in the perception of fishers and fish traders}

Based on the interview results, respondents understood that formaldehyde, as a preservative, has prohibited the government and is harmful to consumers' health. However, anglers do not fully understand that poor handling onboard during harvest and inadequate storage conditions can naturally form formaldehyde in fish. In general, fishing boats have used refrigerators to store and freeze fish, but they still carry out handling by throwing fish, which causes the fish to be injured. The quality of fish raw materials plays an essential role in the quality of the final product; if conditions such as temperature, cleanliness or handling methods, and transportation are neglected, it will accelerate the spoilage process and reduce the fish [23]. Anglers understand that environmental factors determine the formation of natural formaldehyde in fish, but they are not worried because they do not show a direct health impact on consumers.

Based on previous research, fish traders in the estuary have just learned that moonfish contain natural formaldehyde [37]. Moonfish was prohibited from landing at the port of Jakarta; however, these fish were supplied from Benoa Harbor, Bali using refrigerated cars. Moonfish is still found for sale by fish traders in the modern fish market of Muara Baru because it is still often sought after by buyers and its low price. Based on interviews, buyers who can use this fish are food stalls and catering entrepreneurs. This fish is preferred because it tastes delicious and is white so that consumers are interested in eating it.

\section{Conclusion}

Formaldehyde in fish stored at frozen temperatures is still formed during the storage process, as seen from increasing the amount of formaldehyde measured in fish meat. Based on these studies' results, formaldehyde found in four types of fish is naturally occurring formaldehyde. As seen in the test results of hardtail scad and mackerel scad on the 0th day of testing, the detected formaldehyde was $0 \mathrm{mg} / \mathrm{kg}$, and on the 18 th day, it was 1.06 and $1.65 \mathrm{mg} / \mathrm{kg}$ with new conditions, TVB levels. below $20 \mathrm{mgN} / 100 \mathrm{~g}$. Meanwhile, moonfish and rank goby fish since the beginning of the test contained formaldehyde, which increased until the 18th day, namely 7.45 and $14.37 \mathrm{mg} / \mathrm{kg}$, where freshness decreased quality with TVB levels above $20 \mathrm{mgN} / 100 \mathrm{~g}$. Based on previous research results, as long as the fish did not reach a maximum formaldehyde concentration exceeding $15 \mathrm{mg} / \mathrm{kg}$, the fish was relatively safe for consumption.

Lack of supervision and counseling from the government regarding the dangers of natural formaldehyde content in fish causes a lack of fishers' awareness in maintaining fish quality. Therefore, stakeholders, including government and policymakers, must take several priorities to formulate appropriate risk management strategies regarding the natural formaldehyde content in fish because the risk of natural formaldehyde hazards to health is the same as formaldehyde added illegally to food. 


\section{Acknowledgements}

This research is funded by the Grant of Indexed International Publication for Master Student (PUTI Q4) Universitas Indonesia 2020 with contract number: NKB2552/UN2.RST/HKP.05.00/2020.

\section{References}

1. Z. M. Surahman, I. Hanningtyas, D. Aristi, F. Cahyaningrum, E. Laelasari, Factors related to the presence of formaldehyde in the salted fish trade in Ciputat, Indonesia, Malaysian Journal of Medicine and Health Scinces. 15,3, 89-94 (2019)

2. A. Nuraini, T. Nurhayati, M. Nurilmala, Activity of Trimethylamine-N-Oxide Demethylase (TMAOase) in the Forming of Natural Formaldehyde in Greater Lizardfish (Saurida tumbil), Jurnal Pengolahan Hasil Perikanan Indonesia.. 20,3,549558 (2017) https://doi.org/10.17844/jphpi.v20i3.19811

3. M. Yasin, N. Irawati, A.H. Zidan, Kismiyati, A.T. Mukti, A.Soegianto, D.K.P. Rosalia, R.A. Wardani, M. Khasanah, H.J. Kbashi, A.M. Perego, Fiber bundle sensor for detection of formaldehyde concentration in fish, Optical Fiber Technology, 52, (2019) https://doi.org/10.1016/j.yofte.2019.101984

4. WHO, The World Health Organization Report 2002: reducing risks, promoting healthy life, France (2002) https://www.who.int/whr/2002/en/whr02 en.pdf?ua=1

5. I. Jeyasanta, P. Jamila, Quality characteristics including formaldehyde content in selected seafoods of Tuticorin, southeast coast of India, International Food Research Journal, 25, 1, 293-302 (2018)

6. U. Anissah, A. K. Putri, G. R. Barokah, An estimation of endogenous formaldehyde exposure due to consumption of Indonesian opah fish (Lampris guttatus) in three major export destination countries, Squalen Bulletin Marine and Fisheries Postharvest and Biotechnol, 14,1, (2019) http://dx.doi.org/10.15578/squalen.v14i1.369

7. FAO, The State of World Fisheries and Aquaculture 2018 - Meeting the sustainable development goals, Rome, Licence: CC BY-NC-SA 3.0 IGO, (2018) http://www.fao.org/documents/card/fr/c/I9540EN/

8. L. S. Jawahar, C. John, M. Shafeekh, T. K. Anupama, T. V. Sankar, Retention of residual formaldehyde in treated Indian mackerel (Rastrelliger kanagurta) under iced storage and related food safety concern, Indian J. Fish., 64, 4, 87-93, (2017) https://doi.org/10.21077/ijf.2017.64.4.61228-12

9. J. Li, J. Zhu, L. Ye, Determination of Formaldehyde in Squid by High-Performance Liquid Chromatography, Asia Pac. J. Clin. Nutr., 16, 1, 127-130, (2007) https://doi.org/10.6133/apjen.2007.16.s1.24

10. S. Bhowmik, M. Begum, A. Hossain, M. Rahman, A. K. M. N. Alam, Determination of formaldehyde in wet marketed fish by HPLC analysis : A negligible concern for fish and food safety in Bangladesh, Egyptian Journal of Aquatic Research, 43, 3, 245248, (2017) https://doi.org/10.1016/j.ejar.2017.08.001

11. EFSA, Endogenous formaldehyde turnover in humans compared with exogenous contribution from food sources, EFSA Journal., 12, 2, (2014) 
https://doi.org/10.2903/j.efsa.2014.3550

12. IARC, Evaluation of carcinogenic risks to humans: Wood Dust and Formaldehyde, 62. UK (1995) https://publications.iarc.fr/Book-And-Report-Series/Iarc-MonographsOn-The-Identification-Of-Carcinogenic-Hazards-To-Humans/Wood-Dust-AndFormaldehyde-1995

13. M. A. A. Mamun, M. A. Rahman, M. K. Zaman, Z. Ferdousi, M. A. Reza, Toxicological effect of formalin as food preservative on kidney and liver tissues in mice model, IOSR Journal Environmental Science Toxicology Food Technology, 8, 9, 47-51, (2014) https://doi.org/10.9790/2402-08924751

14. F. Nowshad, M. N. Islam, M. S. Khan, Concentration and formation behavior of naturally occurring formaldehyde in foods, Agric. Food Secur, 7, 1, 1-8, (2018) https://doi.org/10.1186/s40066-018-0166-4

15. A. Songur, O. A. Ozen, M. Sarsilmaz, The Toxic Effects of Formaldehyde on the nervous system, 105-118, (2010) https://doi.org/10.1007/978-1-4419-1352-4 3

16. P. Wahed, M. A. Razzaq, S. Dharmapuri, M. Corrales, Determination of formaldehyde in food and feed by an in-house validated HPLC method, Food Chem., 202, 476-483, (2016) http://dx.doi.org/10.1016/j.foodchem.2016.01.136

17. National Standardization Agency of Indonesia, Threshold Value (TLV) of chemicals in workplace air SNI 19-0232-2005, (2005) https://dokumen.tech/document/sni-190232-2005-nab-zatkimia-udara-tempat-kerja.html

18. A. S. Murniyati, Sunarman, Pendinginan Pembekuan dan Pengawetan Ikan (Refrigeration Freezing and Preserving Fish), Yogyakarta. Kanisius, (2000)

19. K. Leelapongwattana, S. Benjakul, W. Visessanguan, N. K. Howell, Physicochemical and biochemical changes during frozen storage of minced flesh of lizardfish (Saurida micropectoralis), Food Chem., 90, 1-2, 141-150, (2005) https://doi.org/10.1016/j.foodchem.2004.03.038

20. S. Benjakul, W. Visessanguan, M. Tanaka, Induced formation of dimethylamine and formaldehyde by lizardfish (Saurida micropectoralis) kidney trimethylamine-N-oxide demethylase, Food Chem., 84, 2, 297-305, (2004) https://doi.org/10.1016/S03088146(03)00214-0

21. N. F. Haard, B. K. Simpson, Seafood Enzymes: Utilization and Influence on Postharvest Seafood Quality, New York: Marcel Dekker, Inc, 2000.

22. C. K. S. Saba, S. I. Atayure, F. Adzitey, Assessment of formaldehyde levels in local and imported fresh fish in ghana: A case study in the tamale metropolis of Ghana, $J$. Food Protection, 78, 3, 624-627, (2015) https://doi.org/10.4315/0362-028X.JFP-14$\underline{355}$

23. N. H. Quang, Guidelines For Handling And Preservation Of Fresh Fish For Further Processing In Vietnam, Iceland (Eur): The United Nation University Fisheries Training Programme, (2005)

24. J. T. Murtini, R. Riyanto, N. Priyanto, I. Hermana, Natural Development of Formaldehyde on Some Kinds of Marine Fish during Storage in Crushed Ice, JPB Perikanan, 9, 2, 143-151, (2014).

25. N. Rachmawati, R. Riyanto, = Farida Ariyani, "Formaldehyde Formation in BrownMarbled Grouper (Ephinephelus fuscoguttatus) During Cold Storage," Jurnal 
Pascapanen dan Bioteknologi Kelautan dan Perikanan, 2, 2, (2007) http://dx.doi.org/10.15578/jpbkp.v2i2.457

26. G. R. Barokah, A. K. Putri, U. Anissah, T. Jovita Murtini, Formaldehyde Formation and Decreasing Quality of Beautiful Grouper Fish (Epinephelus fuscoguttatus $\times$ E. microdon) During Storage At Freezing Temperature, Jurnal Pascapanen dan Bioteknologi Kelautan dan Perikanan, 13, 1, 71-78, (2018) http://dx.doi.org/10.15578/jpbkp.v13i1.511

27. J. W. Creswell, Research Design Approaches to Qualitative, Quantitative, and Mixed Methods. USA, SAGE Publication, Inc., (2014)

28. A. K. Putri, Probabilistic Health Risk Assessment Due to Natural Formaldehyde Intake through Opah Fish (Lampris guttatus) Consumption in Indonesia, Squalen Bull. Mar. Fish. Postharvest Biotech., 13, 2, (2018)

29. H. E. Irianto, S. Giyatmi, Teknologi Pengolahan Hasil Perikanan (Fishery Product Processing Technology), Jakarta, Universitas Terbuka, (2015)

30. N. Nordin, A. B. Fatimah, Y. C. B. Farhana, Formaldehyde content and quality characteristics of selected fish and seafood from wet markets, International Food Research Journal, 18, 1, 125-136, (2011)

31. National Standardization Agency of Indonesia, Chemical Test Method - Part 8: Determination of Total Volatile Base Nitrogen (TVB-N) and Trimethyl Amine Nitrogen (TMA-N) Levels in Fishery Products SNI No. 2354.8: 2009, (2009)

32. Hesis, Formaldehyde. Hazard Evaluation System \& Information Service, California Department of Public Health California Department of Industrial Relations, (2011)

33. C. G. Sotelo, C. Pineiro, R. I. Perez Martin, Denaturation of fish proteins during frozen storage: role of formaldehyde, Z Lebensm Unters Forsch., 200, 1, (1995) https://doi.org/10.1007/BF01192902

34. M. R. Adams, M. O. Moss, Food Microbiology 3rd edition, University of Surrey, Guildford UK, RSC Publishing, (2008)

35. F. Bianchi, M. Careri, M. Musci, A. Mangia, Food chemistry fish and food safety: Determination of formaldehyde in 12 fish species by SPME extraction and GC - MS analysis, Food Chem., 100, 3, (2007) https://doi.org/10.1016/j.foodchem.2005.09.089

36. T. Nash, The colorimetric estimation of formaldehyde by means of the Hantzsch reaction, Biochem. J., 55, 3, (1953) https://doi.org/10.1042/bj0550416

37. T. D. Widyaningsih, E. S. Murtini, Alternatif Pengganti Formalin pada Produk Pangan (Alternative to formaldehyde in food products). Surabaya, Trubus Agrisarana, (2006) 